\title{
Histopathological Changes in Temporal Epilepsy
}

\author{
Assaad Fawaz and Al Khani Raydeh \\ Damascus University/Faculty of medicine \\ Syria
}

\section{Introduction}

A wide variety of lesions have been reported in the different studies of epilepsy in the literature; though the question is still raised if these observed lesions are the cause or the consequence of seizures. The lesions that might play a role in the onset, maintenance and progression of pharmacoresistance of epileptic seizures, as well as the lesions that might results in are not yet well predicted and comprehensible.

\section{Histopathological findings}

A confusing array of histopathological findings was reported in the studies of temporal lobe and hippocampus in chronic pharmacoresistant temporal epilepsy, in the literature. We would like to suggest that these findings could be grouped in certain categories:

\subsection{Malformations}

Many types of malformations were reported in epileptic series; these included the following: (Wolf et al, 1993-1995; Prayson et al, 1996; Volk et al, 1997; Armstrong et al, 2007; Al Khani \& Assaad, 2008):

\subsubsection{Subependymal nodular cortical heterotopias and band heterotopias [double cortex]}

Congenital lesions composed of heterotopic cortical tissue in a periventricular subependymal location; they are closely associated with epilepsy (d'Orsi, 2004; Armstrong et al, 2007) (see fig. 1-2)

\subsubsection{Cortical malformations}

They include lissencephaly (smooth or nearly smooth cortical surface), hemimegalencephaly (enlarged hemisphere) and pachygyria-polymicrogyria (Sisodiya et al, 2004; Armstrong et al, 2007). Gyral fusion and abnormal elongation of a sulcus are other reported findings (see fig.3) (Al Khani \& Assaad, 2008).

It is suggested that cortical malformations can both form epileptogenic foci and alter brain development in a manner that causes a diffuse hyperexcitability of the cortical network (chevaussus et al, 1999). 


\subsubsection{Neuronal and glioneuronal malformations}

These malformations are composed of foci of havardous atypical neurons and Glioneuronal tissue. They overlap with neuronal and neuronal-glial tumors (Wolf et al, 1993-1995; prayson et al, 1996; Volk et al, 1997; Al Khani \& Assaad, 2008), (see paragraph 2.4)

\subsubsection{Microdysgenesis}

This includes the following lesions of abnormal migration (Armstrong et al, 2007):

1. Ectopic neurons in the white matter in greater than normal numbers

2. Gray matter heterotopias: foci of displaced "gray matter" composed of neurons, glia, and neuropil characteristics.

3. Hamartia that are microscopic collections of small, round "oligodendroglia-like" cells. They may be observed in the cortex or in the white matter and have some staining characteristics of immature neurons

4. Perivascular glial nuclei refer to the presence of chains of bare glial nuclei in the white matter

5. Neuronal clusters

\subsubsection{Vascular malformations}

Vascular malformations are known to cause seizures; notably arteriovenous malformations. All vascular tumors of the central nervous system are considered as malformative lesions (Louis et al, 2007).

\subsection{Cortical dysplasia/dysgenesis}

The histopathology of "cortical dysplasia" or "cortical dysgenesis" as described by the authors (Taylor et al, 1971; Prayson et al, 1995-1996; Frater et al, 2000; Wang et al, 2006; Armstrong et al, 2007; Bernasconi et al, 2011) includes a variety of structural changes which could be focal, multifocal, or diffuse, resulting in changes in the neuronal network inciting seizures attacks: neuronal migration abnormalities, diffuse architectural disorganization of the cortex with cortical laminar disruption, gyral fusion, clusters of atypical neurons and glial cells within the cortex, malalignment of neurons, neuronal cytomegaly, increased numbers of molecular layer neurons, the presence of large neurons displaying a pyramidal or round shape, ballooned cells, and a high concentration of neurofilaments in giant neurons and of glial intermediate filaments in ballooned cells, evoking disruption of cell differentiation and maturation and an impairment of synaptogenesis (Garbelli et al, 1999). The term "cortical dysgenesis or disorganization" might be more appropriate.

Classification schemes were described; the widely adopted is that described by palmini et al. This classification distinguished two types of cortical dysplasia based of the presence or absence of dysmorphic neurons or balloon cells, as follows (palmini et al, 2004):

Type I:

IA: Isolated architectural abnormalities, usually laminar or columnar disorganization, but no dysmorphic neurons

IB: Architectural abnormalities, giant cells or immature neurons can be found Type II:

IIA: Architectural abnormalities with dysmorphic cells are found, but no balloon cells

IIB: Architectural abnormalities with both dysmorphic cells and balloon cells

Changes of the above described "cortical dysplasia" are observed in all cases of epilepsy in some studied series (Al Khani \& Assaad, 2008) (fig 3\&4). Irregular brain surface and 


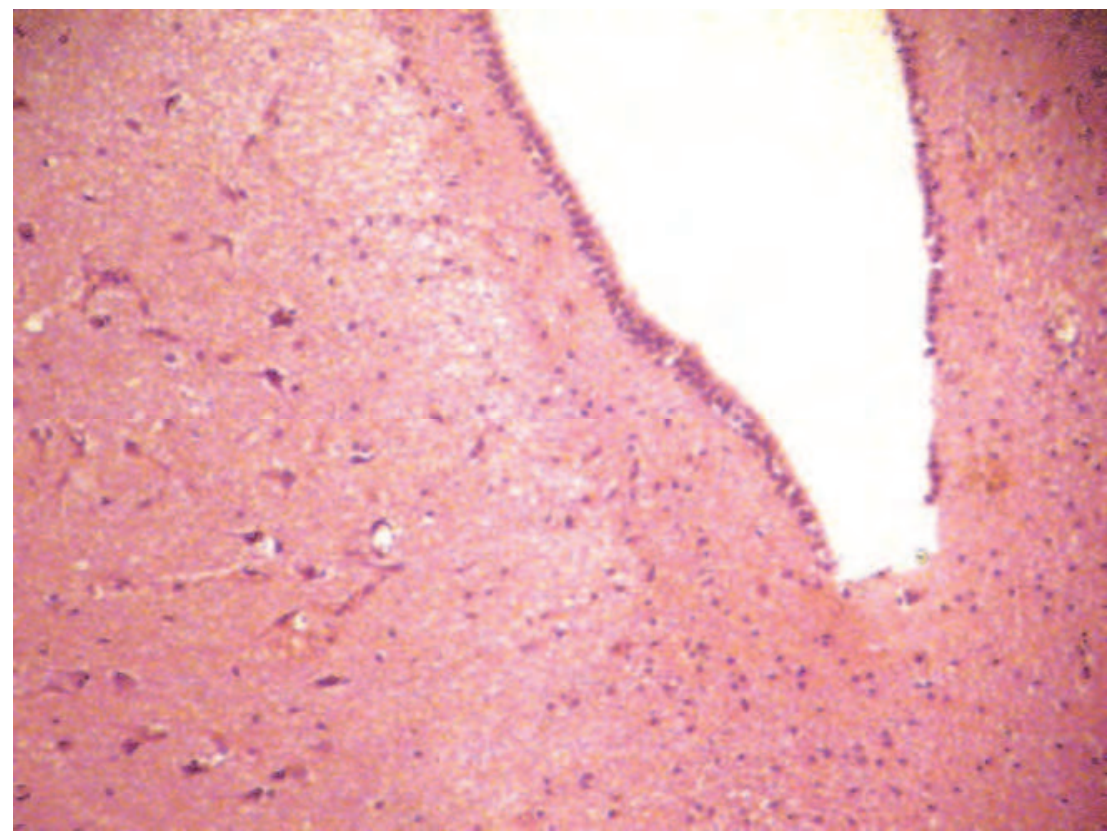

Fig. 1. Subependymal nodular cortical heterotopia observed at the left side of the figure. The columnar ependymal cells are clearly seen (HE stain).

irregular cortical thickness were also described; that might be the consequence of neuronal reorganization associated with glial cell reaction.

Cortical dysgenesis might begin as an in utero migrational abnormality (Sprifeafico et al, 1998) so some authors put these lesions under the category of malformations (Armstrong et al, 2007), or as an acquired cortical dysplasia in response to perinatal brain damage (MarinPadilla et al, 1999). This alteration becomes an ongoing process that affects the structural and functional differentiation of neurons, synaptic profiles, fiber distribution, glial elements, and vasculature. Cortical dysplasia/disorganization becomes worse with the recurrence of seizures and exacerbates neuronal damage.

\subsection{Signs of neuronal injury, neuronal lysis, apoptosis and neuronal loss}

Neuronal damage and loss have been well documented in studies of epilepsy. Neuron loss is mainly observed in CA2\& CA1 sectors of ammon horn (fig 5) and it might be observed in the other sectors in the advanced cases; it is found to be followed by axonal and mossy fibers sprouting and reorganizing (El Bahh et al, 1999; Armsrong et al, 2007). Neuron injury and loss was evident in many series, affecting especially the pyramidal cells in the cortex and the granular cells in the dentate gyrus (dentate nucleus) (Proper et al, 2000; Al Khani and Assaad, 2008) (fig.6-9). The survived cells showed variability in size and shape, edema and vacuolization, and disorganization. Unexplained $\mathrm{PAS}^{+}$material was also described in some observations in the cytoplasm of the injured neurons. Neuronal lysis and apoptosis were noted in our study adjacent to injured neurons. Neuronal damage especially affecting these neurons was well documented in animal experimental models.(Bouilleret et al, 2000) 


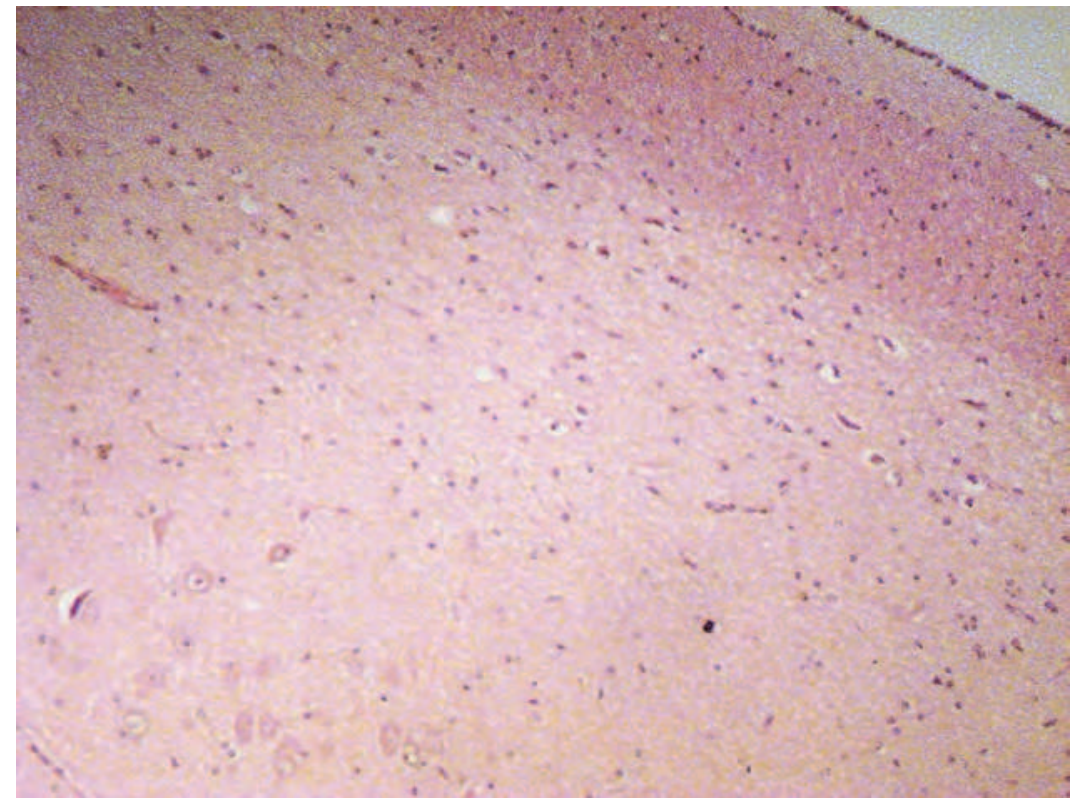

Fig. 2. Subependymal nodular cortical heterotopia showing cluster of atypical neurons at the left lower side (HE stain).

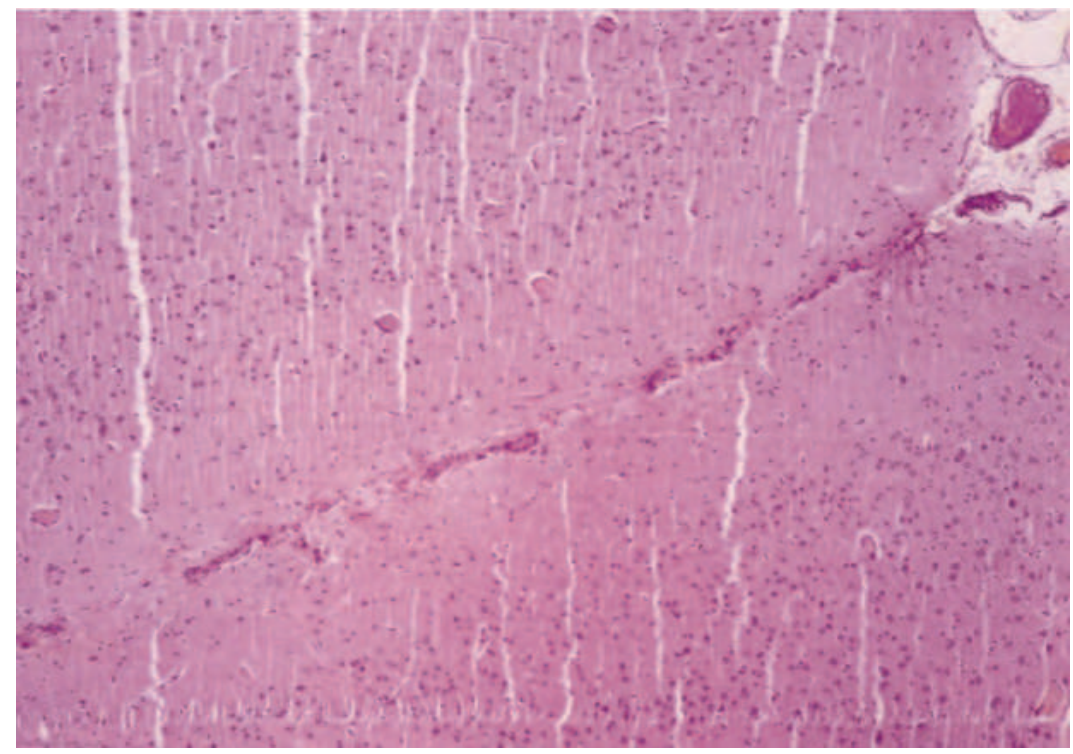

Fig. 3. Gyral fusion in the temporal lobe showing focal complete adhesion of the nervous tissue in "slits-shape" (HE stain). Cortical dysplasia is also noted at both sides of the sulcus (HE stain). 
The loss of a critical number of interneurons in the dentate gyrus was suggested as a possible cause of seizure initiation (Fritschy et al, 1999) It was suggested that childhood seizures can damage or alter the postnatally developing granule cells of the human hippocampus, and that early neuron loss and aberrant axon circuits may contribute to chronic hippocampal seizures (Mathern et al, 1996). The role of apoptosis-related genes and the activation of the programmed death pathway were well documented by some authors, explaining that neuronal loss (Uysal et al, 2003; d'Orsi et al, 2004; Niquet et al, 2004; ). Apoptotic neurons were noted beside neuron lysis; these two forms of cell death in histopathological findings might contribute to neuron loss (Becker et al, 1999; Al Khani \& Assaad 2008) (fig 7).

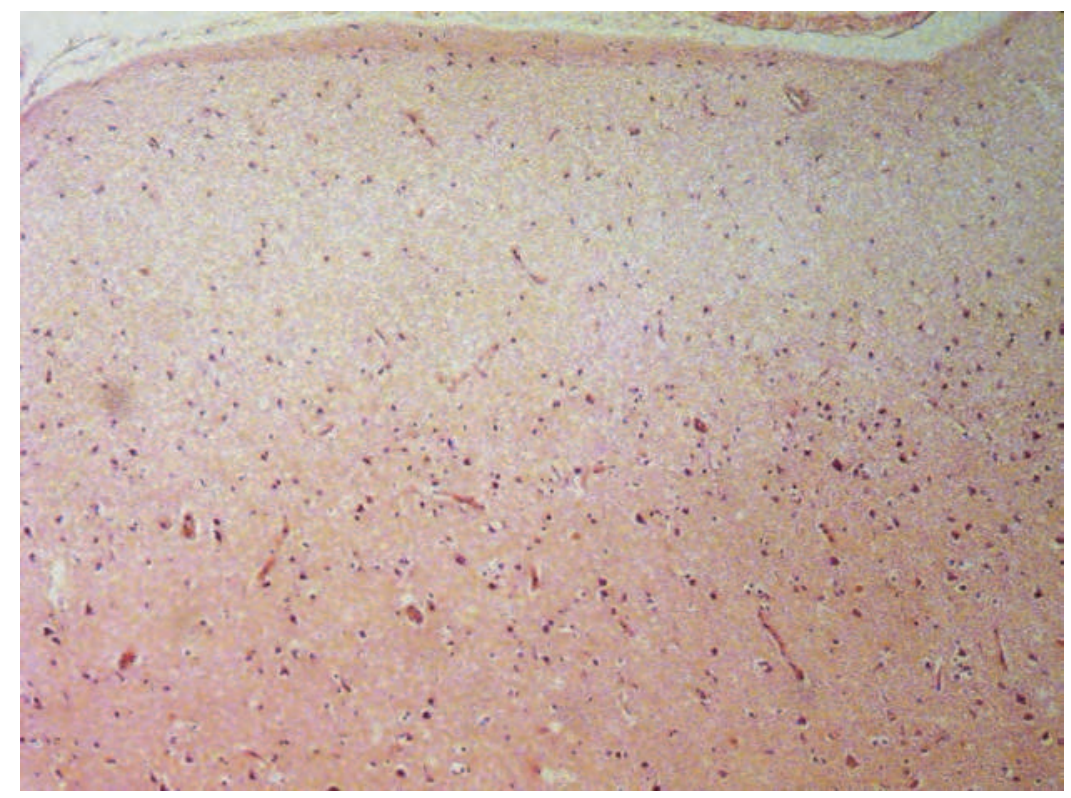

Fig. 4. Cortical dysplasia showing architectural abnormalities (HE stain). Note the subpial gliosis in this figure.

\subsection{Tumors and hamartomatous tumors}

Some tumors are known to be frequently associated with epilepsy, such as dysembryoplastic neuroepithelial tumors (DNETs), ganglioneuromas and gangliogliomas, which can be either bilateral or multifocal (Barbosa et al, 1999; Whittle et al, 1999; Rosemberg et al, 1998; Al Khani and Assaad, 2008; Louis et al, 2007) (fig. 10). The hamartomatous origin of these tumors is suggested by some authors, as they are composed of mature multiple cell types (Gyure et al, 2000; Louis et al, 2007) Other low-grade tumors were reported in some cases of pharmacoresistant temporal epilepsy, such as xanthoastrocytomas (fig.11), low-grade astrocytomas, oligodendrogliomas, oligoastrocytomas, vascular tumors (Oda et al, 1998) and mixed or composite tumors (Hirose et al, 1998) Their incidences varies widely from one series to another; they were found with high percentages in some series, where most of the glioneuronal tumors were 


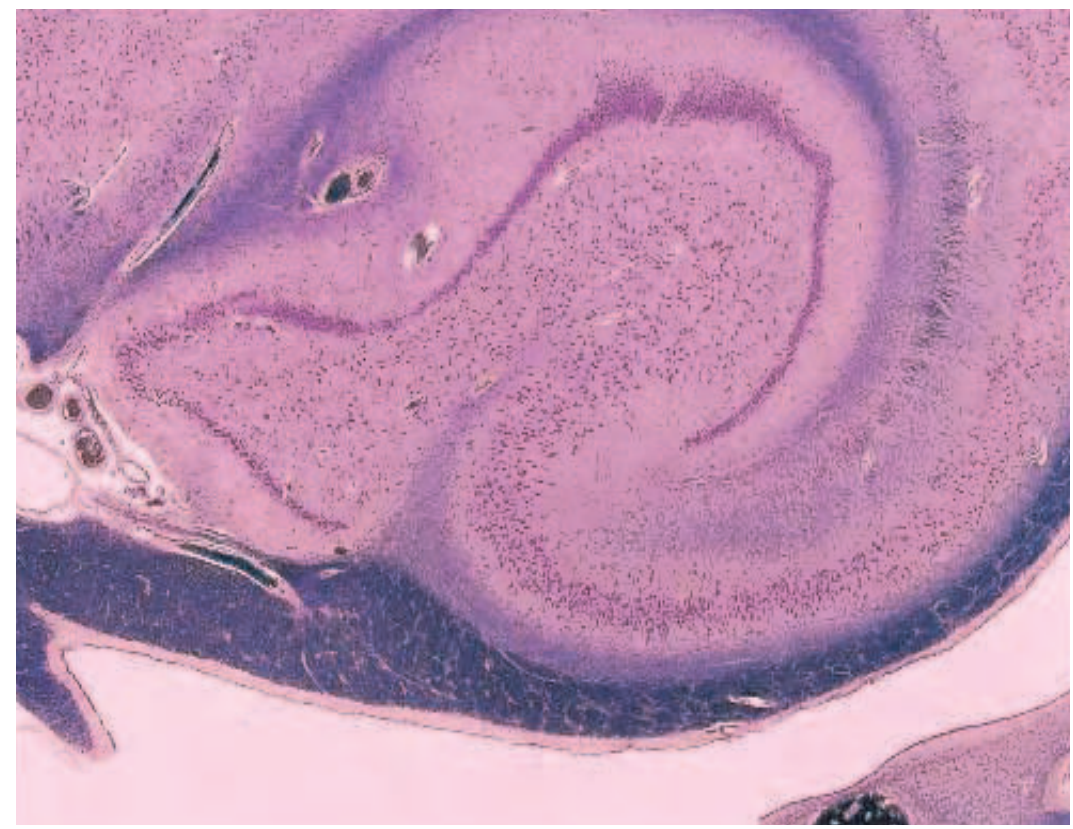

Fig. 5. The dentate gyrus and the four sectors of ammon's horn (cresyl violet stain; Armstrong et al, 2007).

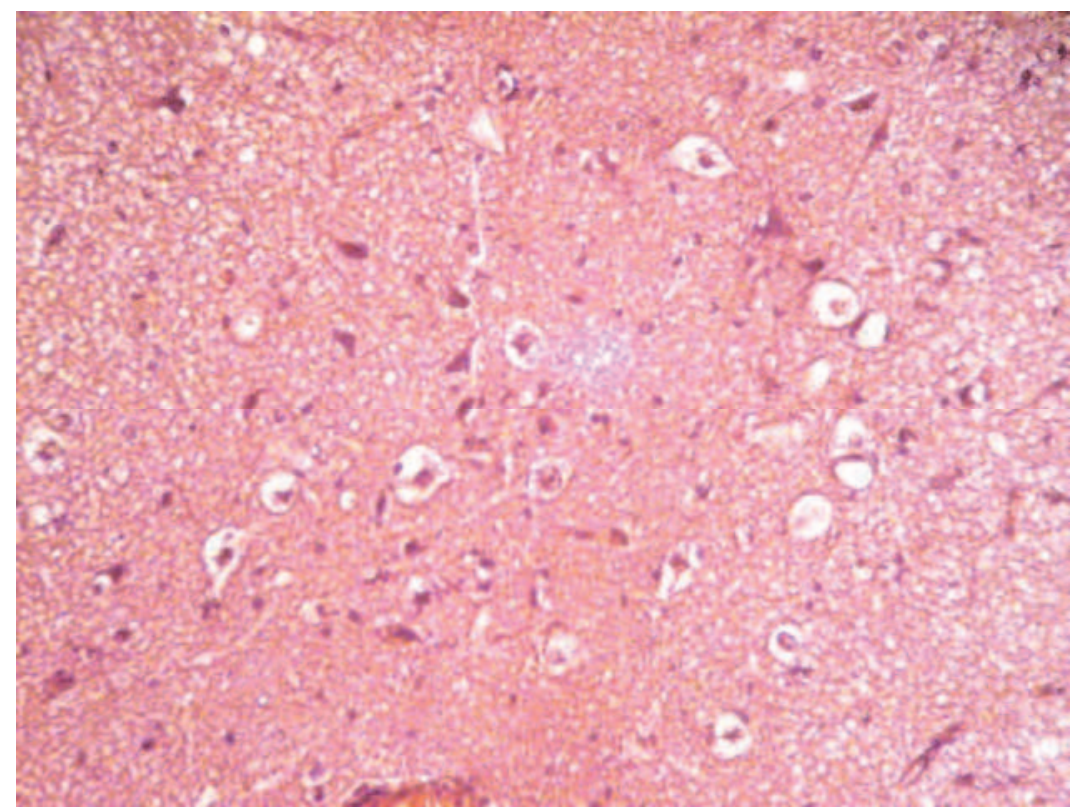

Fig. 6. Cluster of injured vacuolated neurons (HE stain). 


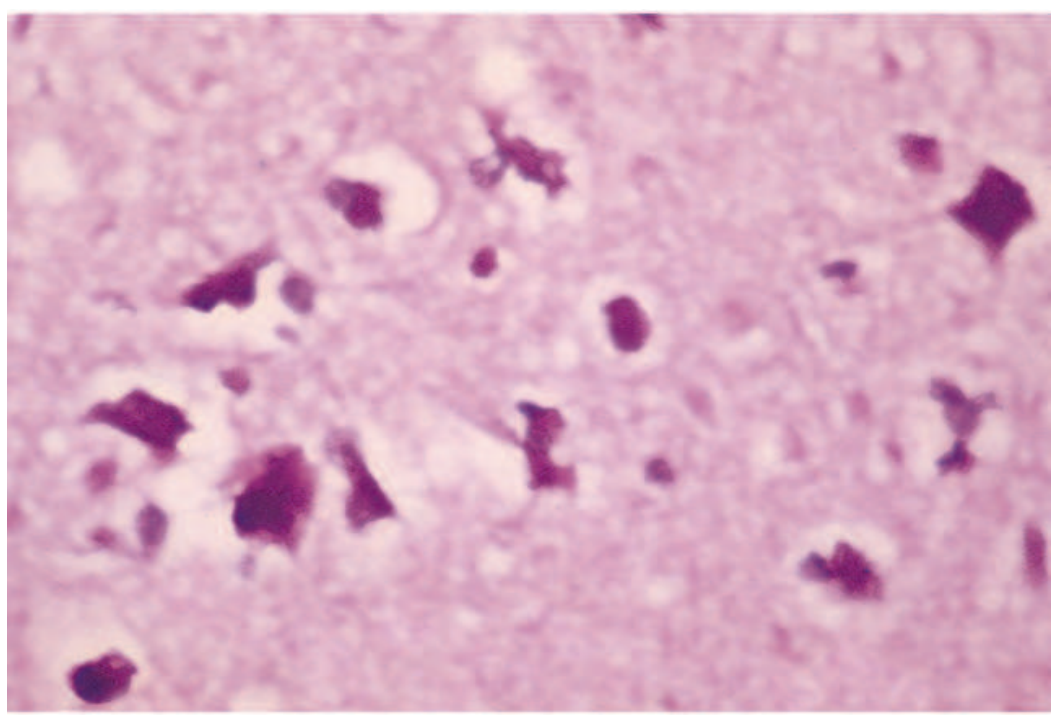

Fig. 7. Cluster of injured neurons revealing variation in sizes, vacuolization, shrinking, apoptosis, lysis, and intracytoplasmic $\mathrm{PAS}^{+}$material (PAS stain)

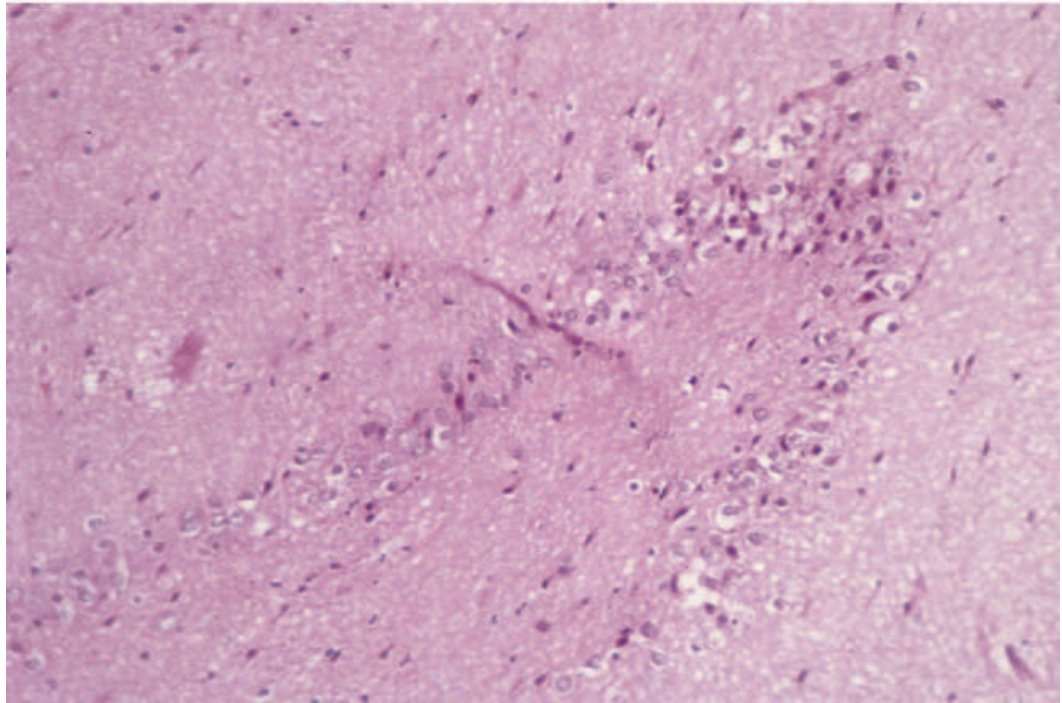

Fig. 8. Quasi complete loss of pyramidal cells in CA1 sector, with signs of neuron injury in the dentate gyrus (CA2 sector) with vacuolization, balloonization and loss of the granular neurons (HE stain). 


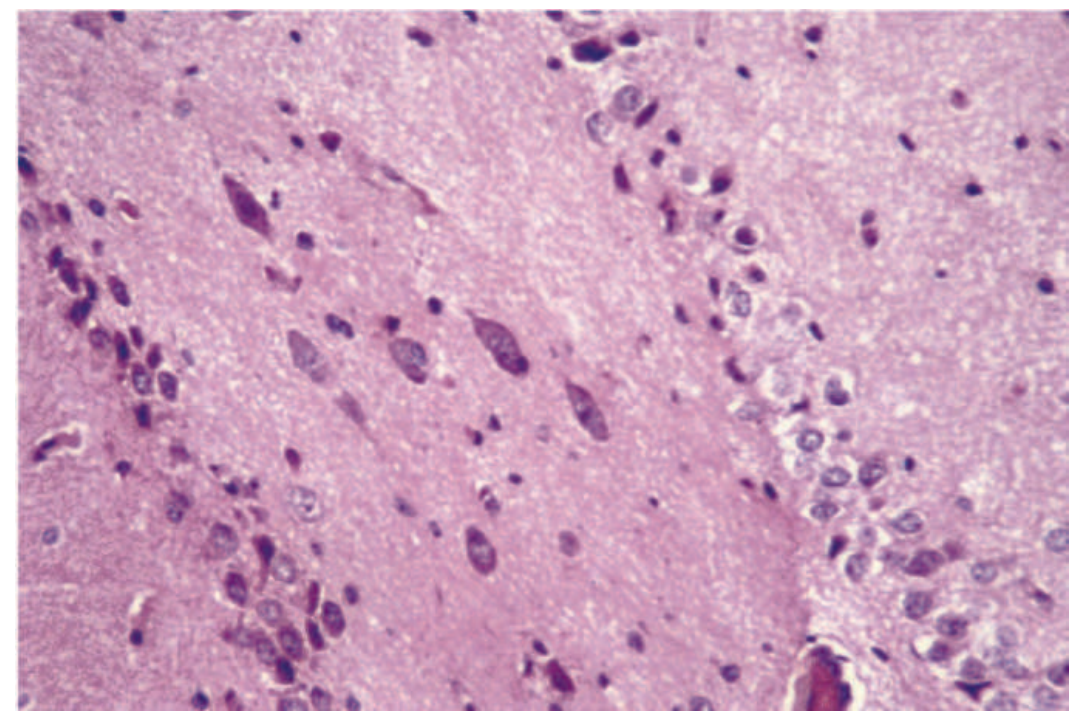

Fig. 9. Neuronal injury in the granular cells of the dentate gyrus (CA2 sector) with atypical and giant pyramidal neurons in CA1 sector. Abnormal intracytoplasmic inclusions are also noted (HE stain).

bifocal, multifocal, or associated with each other, with transitional zones or "composite tumors" as described by some other authors (Prayson et al, 1999; Al Khani \& Assaad, 2008) (fig.12). The juxtaposition of these tumors, and the transition between DNETs, gangliogliomas, or hamartomatous glioneuronal lesions might support the hypothesis that all these tumors are of hamartomatous origin. The relationship and the transition between these lesions have also been reported other authors (Hirose et al, 1998; Moreno et al, 2001).

\subsection{Inflammation}

Different causes of inflammatory changes are described in the cases of epilepsy; the most famous is Rasmussen's encephalitis that is frequently reported in series of epilepsy (Frater et al, 2000; Prayson et al, 1999; Al Khani \& Assaad, 2008) It is defined by lymphoid infiltration of the cerebrocortical perivascular compartment and neuropil, microglial nodule formation, astrogliosis, and variable neuronal loss. Cytomegalovirus and herpes virus HSV1 are found in some cases.(Jay et al, 1995).

Inflammation caused by protozoan, parasites, and brain abscess was sometimes accompanied by seizures (Armstrong et al, 2007). Chronic encephalitis without evidence of pathogenic agent is sometimes reported (Prayson et al, 1999; Al Khani \& Assaad, 2008) .

\subsection{Ischemic and hemorrhagic disorders}

Ischemic changes and infarct were reported in some series; this might results in severe atrophy (fig. 13). Abnormal blood supply was noted by some authors (Al Khani \& Assaad, 2008; Fratel et al, 2000; Li et al, 1999; Prayson et al, 1999; Bernhardt et al, 2009). Hematomas were associated in some series with chronic epilepsy (Hisada et al, 1999; Al Khani \& Assad, 2008). 


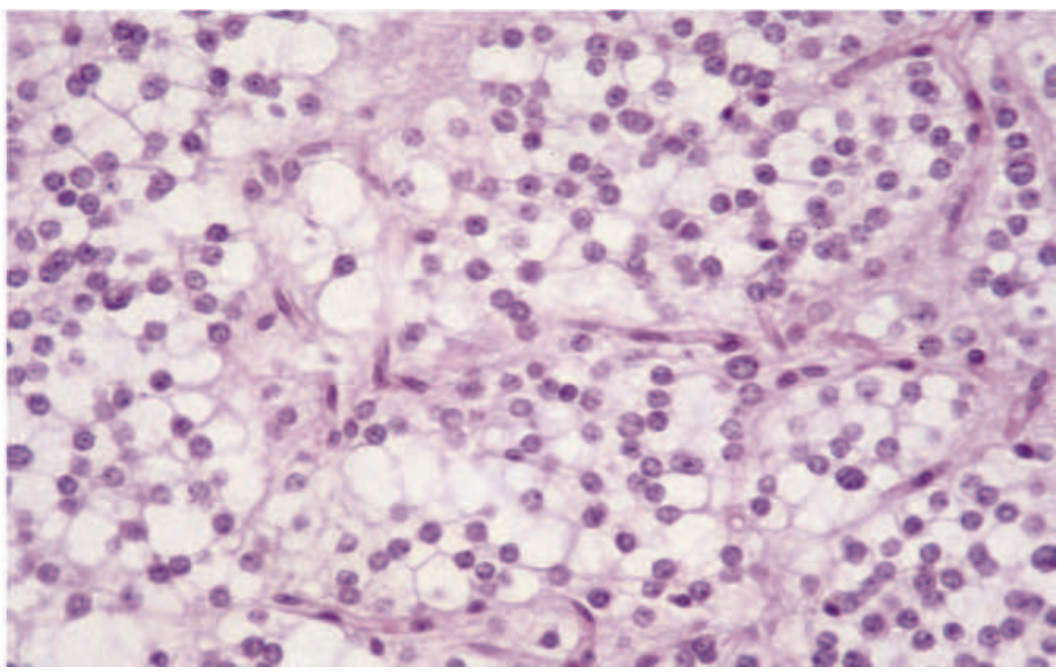

Fig. 10. Dysembryoplastic neuroepithelial tumor is a common tumor found in epileptic cases.

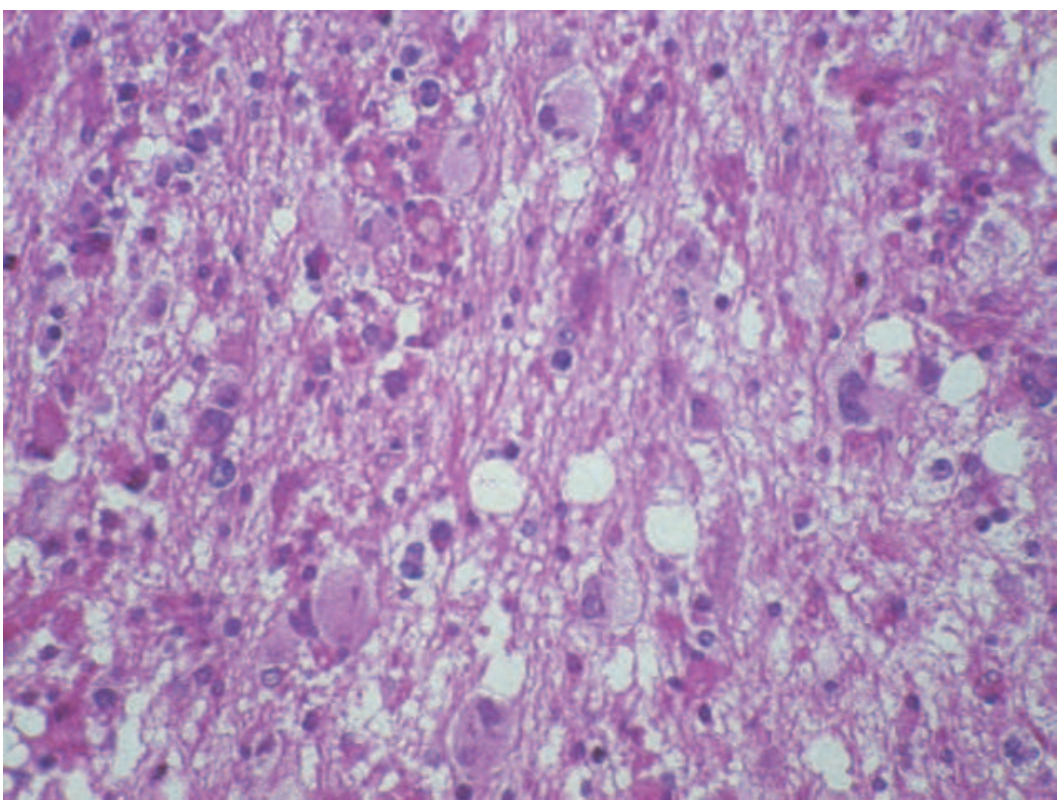

Fig. 11. Xanthoastrocytoma is a rare low-grade glial tumor that can constitute an epileptogenic focus. 


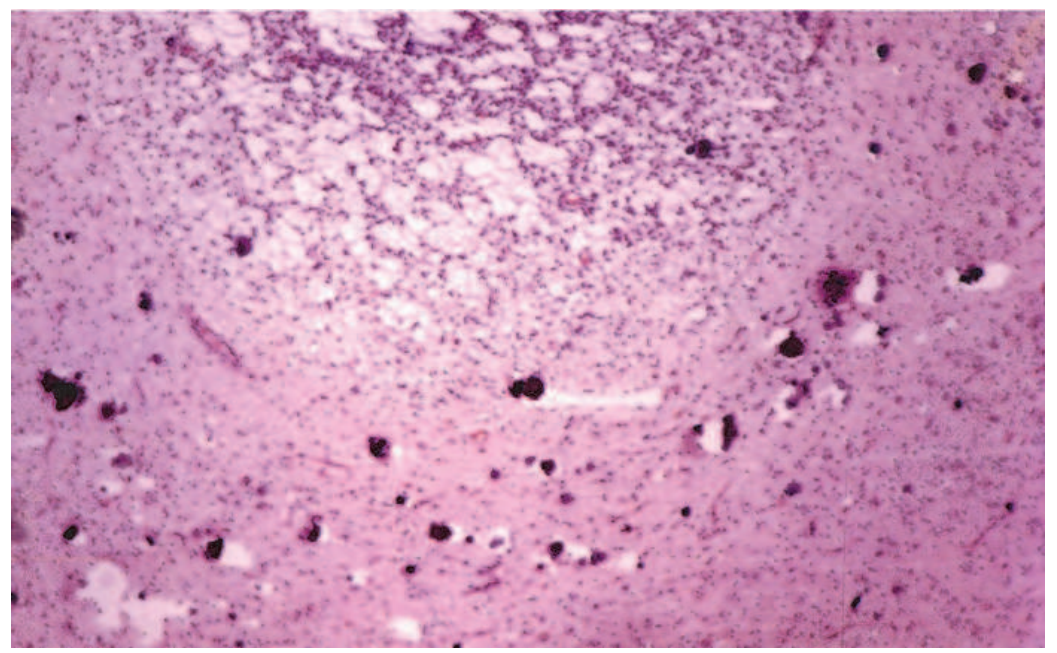

Fig. 12. Dysembryoplastic neuroepithelial tumor at the upper side of the figure, showing transition to ganglioglioma; reinforcing the malformative nature of these tumors.

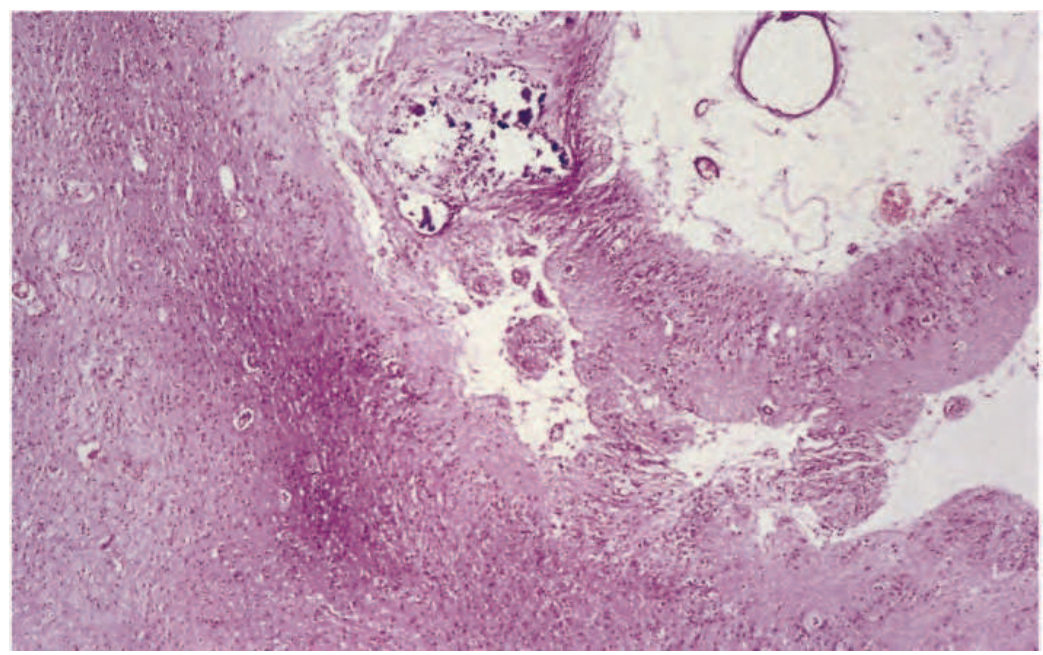

Fig. 13. Severe atrophy of the temporal lobe and the hippocampus due to atypical vascularization. Focal calcification is noted at the middle upper part of the figure (HE stain).

\subsection{Metabolic disorders, vacuolization, and cystic changes}

This was represented by vacuolar degeneration of neurons and glial cells (fig. 14), and cystic changes of the cortical, subcortical or glial tissue, reaching many centimeters in some cases where they could be detected on the macroscopic examination of the cut section; otherwise, they were microscopic findings. Cystic changes of the nervous tissue were constant observations in some refractory epilepsy series; thought they are considered as non-specific findings. These cysts were not alcianophilic, PAS stain was also negative (Al Khani \& 
Assaad, 2008). Progressive metabolic changes were noted, occurring during the development of hippocampal sclerosis in a model of mesial temporal lobe epilepsy (Bouilleret et al, 2000) The progress of metabolic or pathologic abnormalities of temporal lobe epilepsy may not be altered by adequate seizure control, as the presence of an epileptogenic focus might be associated with progressive neuronal injury even in clinically well-controlled patients (Spanaki et al, 2000) This might explain the exacerbation of neuronal damage and nervous tissue injuries with all the pathological changes constantly observed. Some authors found that hippocampal cell loss results in decreased efferent synaptic activity and neuronal activity in the thalamus and basal ganglia, and subcortical hypometabolism, which may reinforce the epileptogenic potential of the mesial temporal lobe discharge (Dlugos et al, 1999). In a studied series of refractory epilepsy, signs of metabolic disorders were noted in all of the cases (Al Khani \& Assaad, 2008).

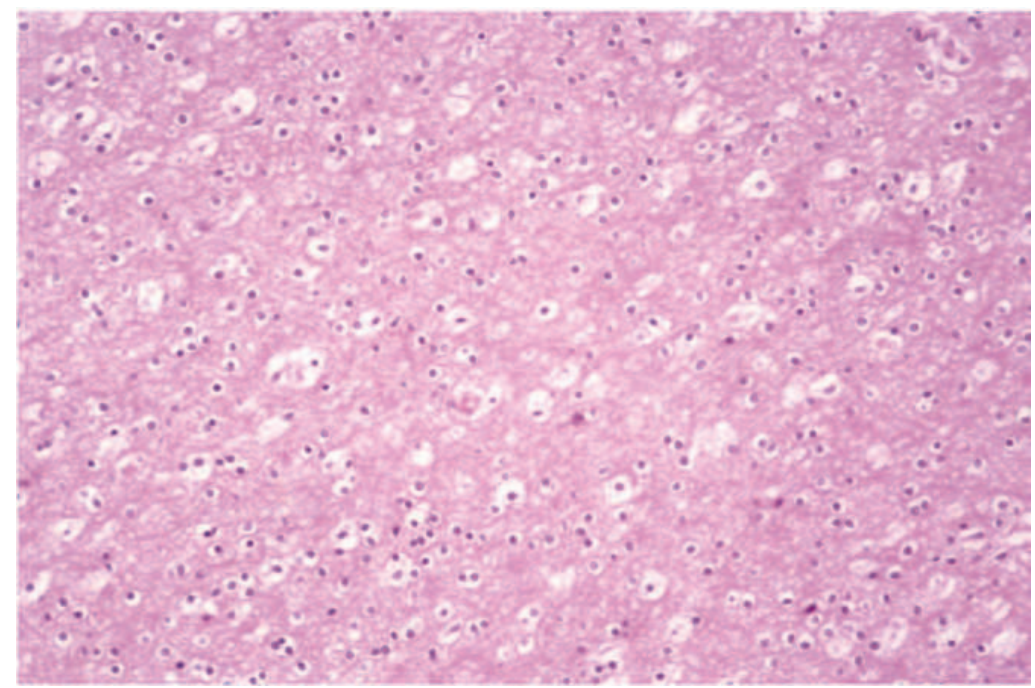

Fig. 14. Vacuolization of the glial cells in the temporal lobe and hippocampus (HE stain).

\subsection{Northern epilepsy}

Other authors found intraneuronal accumulation of cytoplasmic autofluorescent granules in which is called as northern epilepsy (Herva et al, 2000).

\subsection{Sclerosis/gliosis}

Gliosis is noted in all of the reported series of epilepsy with various degrees. Some investigators view hippocampal sclerosis as the primary cause of temporal lobe epilepsy, whereas others interpret the changes to be the result of chronic seizure activity. The macroscopic and radiological term of hippocampal sclerosis is interpreted, on histopathological examination, as astrogliosis associated with neuronal loss (Rushing et al, 1997; Prayson et al, 1999). Astrogliosis or oligoastrogliosis (fig 15) was observed, in varying degrees, in the temporal lobe and hippocampus in all cases of drug resistant epilepsy in some series (Al Khani \& Assaad, 2008), even in patients with no remarkable abnormalities on MRI in the temporal lobe, but with an irregular hippocampal signal on MRI. Cortical gliosis, especially subpial gliosis (fig 4) was always accompanied by advanced cortical dysplasia; this 
leads to believe that progressive gliosis might be a reactive process induced by neuronal injury and loss, seizure attacks, and metabolic disorders. Sclerosis/gliosis might be considered as the end-stage of the all modifications. Focal oligogliosis is sometimes noted (fig 16).

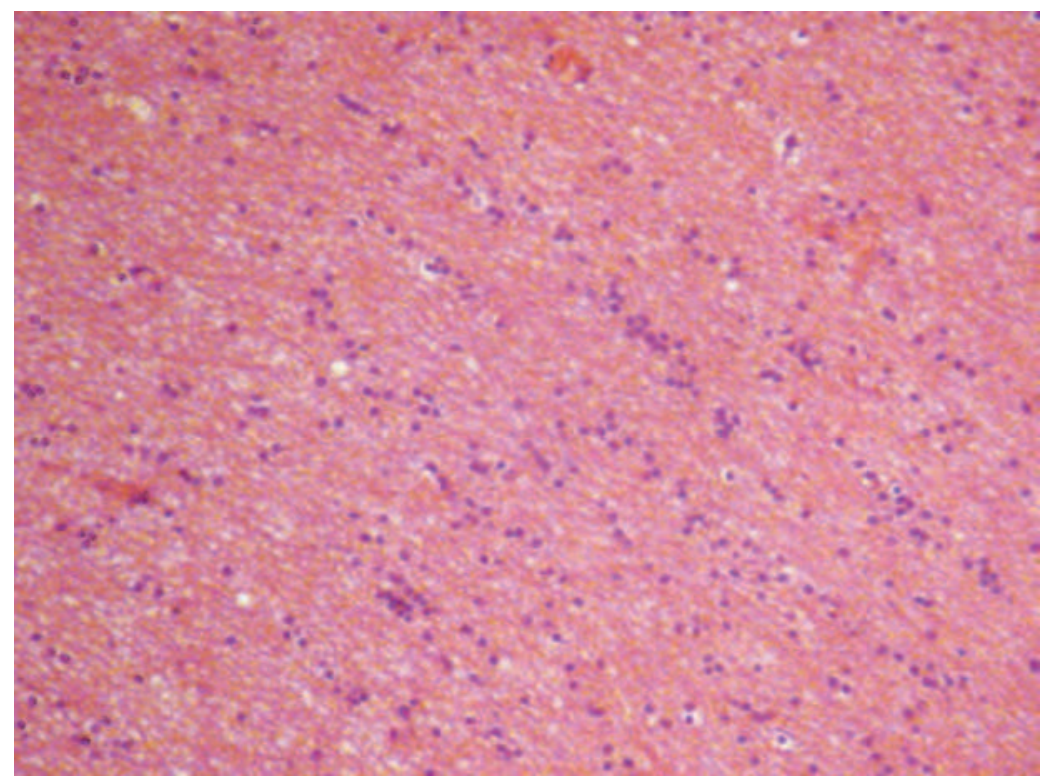

Fig. 15. Oligoastrogliosis in the white matter (HE stain).

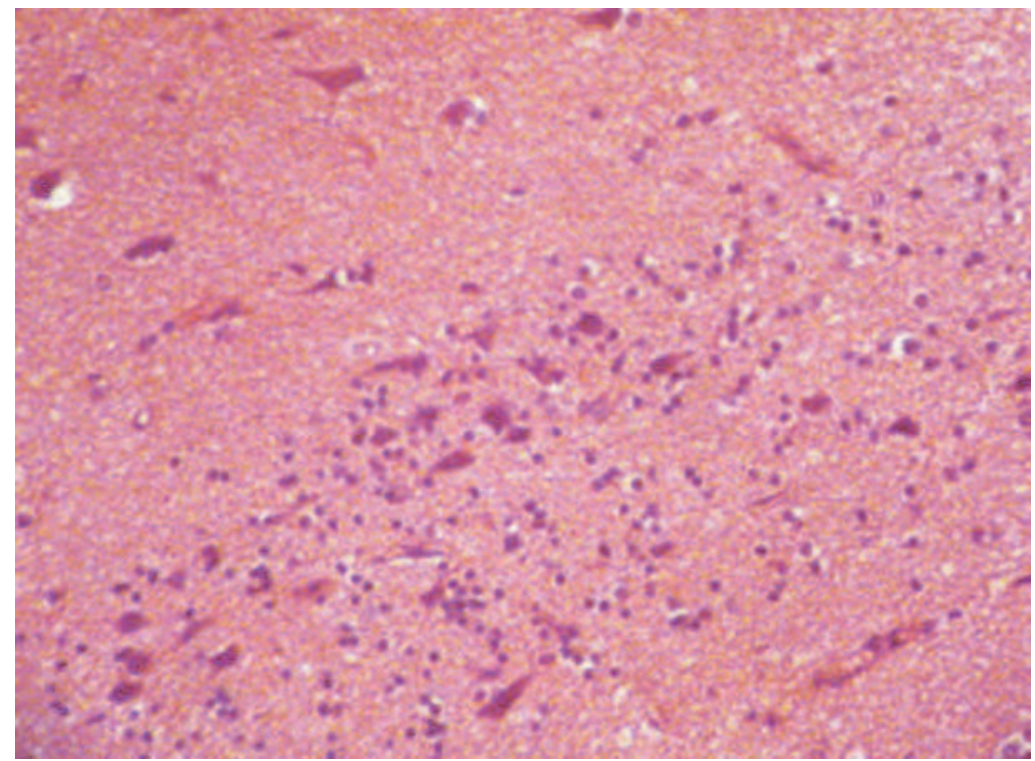

Fig. 16. Focal oligogliosis in a heterotopic subependymal cortical nodule (HE stain). 


\section{Combinations of lesions: "Dual pathology"}

Some authors mentioned that seizure attacks require dual pathology, as several observations revealed combinations of lesions (Jay et al, 1994; Oda et al, 1998; Juhsz et al, 1999; Li et al, 1999; Prayson et al, 2010); for example, the coexistence of brain tumors and cortical dysplasia, neuronal migration disorders and low grade gliomas, lesions having both neoplastic and malformed foci, extrahippocampal lesion plus hippocampal atrophy, and coexistence of hippocampal sclerosis and a potentially epileptogenic cortical lesion. It was also reported that bilateral hippocampal atrophy was found frequently in patients with temporal lobe developmental malformations, and that the presence of bilateral amygdala or amygdalo-hippocampal atrophy was associated with a higher risk of seizure recurrence (Kuzniescky et al, 1999). The multifocality of malformative lesions was well reported by some authors (Wolf et al, 1995; Moreno et al, 2001; Armstrong et al, 2007). In our series (Al Khani \& Assaad, 2008) dual pathology was well documented as tumors were always present in association with other changes, that were almost always seen: cortical dysplasia, astrogliosis, cystic changes, and neuron injury and loss. The presence of bifocal or multifocal tumors and/or hamartomas was another observation to be noted.

\section{Conclusion}

A wide variety of lesions is documented in histopathological study of the temporal lobe and the hippocampus in temporal epilepsy, especially pharmacoresistant epilepsy. Some lesions were constantly present; cortical disorganization, neuron injury and loss, and gliosis. A presumable epileptogenic focus as hamartoma or tumoral lesion is frequently observed. Multiplicity and multifocality of lesions are well documented, reinforcing the hypothesis that the presence of an epileptogenic focus provokes a process of progressive damage of the nervous tissue. The good understanding of these processes and their sequencing, especially those leading to neuron death and loss, might contribute in the prevention of progression of epileptic seizure and the damage of nervous tissue in previously susceptible patients.

\section{References}

Al Khani, R., Assaad, F., (2008). Histopathological findings in chronic pharmacoresistant temporal epilepsy: A pathognomonic combination of lesions maintaining neuron injury? Pan Arab Journal of Neurosurgery, Vol.12, No.2, (October), pp. 86-93, ISSN 1319-6995

Armstrong, D., Halliday, W., Hawkins, C., \& Takashima, S., (2007). Epilepsy, Pediatric Neuropathology: A Text Atlas, pp. 376-384, Springer, ISBN 978-4-431-70246-7, Tokyo, Berlin, Heidlberg, New York

Barbosa Coutinho, L.M., Hilbig, A, Calcagnotto, M.E., et al., (1999). Neuropathology of hard to control epilepsy. Study of 300 consecutive cases. Arqivos de Neuro-psiquiatria, Vol.57, No.2B, (June), pp. 405-14, ISSN 0004-282X

Becker, A.J., Gillardon, F., Blümcke. I, Langendrfer, D., Beck, H., Wiestler, O.D., (1999). Differential regulation of apoptosis-related genes in resistant and vulnerable subfields of the rat epileptic hippocampus. Brain Research and Molecular Brain Research, Vol 67, No.1, (April), pp. 172-6, ISSN 0165-0173

Bernasconi, A., Bernasconi, N, Bernhardt B.C., Schrader, D., (2011). Advances in MRI for 'Cryptogenic' Epilepsy: Histopathology of cortical dysplasia. Nature Reviews. 
Neurology, Vol.7, No.2, pp. 99-108. Accessed on 20 March, 2011. Available from http://www.medscape.com/viewarticle/737007_2

Bernhardt, B.C., Rozen, D.A., Worsley, K.J., et al., (2009). Longitudinal and cross-sectional analysis of atrophy in pharmacoresistant temporal lobe epilepsy. Neurology, Vol.72, No.20, pp. 1747-54, ISSN 0028-3878

Bouilleret, V., Boyet, S., Marescaux, C., Nehlig, A., (2000). Mapping of the progressive metabolic changes occurring during the development of hippocampal sclerosis in a model of mesial temporal lobe epilepsy. Brain Research, No. 852, (January), pp. 25562, ISSN 0006-8993

Chevassus au Louis, N., Baraban, SC., Gaïarsa J.L., Ben Ari, Y., (1999). Cortical Malformations and epilepsy: new insights from animal models. Epilepsia, Vol. 40. No.7, (July), pp. 811-21, ISSN 0013-9580

Dlugos, D.J., Jaggi, J., O'Connor, W.M., et al., (1999). Hippocampal cell density and subcortical metabolism in temporal lobe epilepsy. Epilepsia, Vol.40., No.4, (April), pp. 408-13, ISSN 0013-9580

d'Orsi, G., Tinuper, P., Bisulli, F., et al., (2004). A. Clinical features and long term outcome of epilepsy in periventricular nodular heterotopia. Simple compared with plus forms. Journal of Neurology, Neurosurgery, and Psychiatry, Vol.75, No.6, (June), pp. 873-8, ISSN 0022-3050

El Bahh, B., Lespinet, V., Lurton, D., Coussemacq, M., Le Gal La Salle, G., Rougier, A., (1999). Correlations between granule cell dispersion, mossy fiber sprouting, and hippocampal cell loss in temporal lobe epilepsy. Epilepsia, Vol.40, No.10, (October), pp. 1393-401, ISSN 0013-9580

Frater, J.L., Prayson, R.A., Morris III, H.H., Bingaman, W.E., (2000). Surgical pathologic findings of extratemporal-based intractable epilepsy: a study of 133 consecutive resections. Archives of Pathology \& Laboratory Medecine, Vol.142, No.4, (April), pp. 545-9, ISSN 0003-9985

Fritschy, J.M., Kiener, T., Bouilleret, V., Loup, F., (1999). GABAergic neurons and GABA(A)receptors in temporal lobe epilepsy. Neurochemistry International, Vol.34, No.5, (May), pp. 435-45, ISSN 0197-0186

Garbelli, R., Munari, C., De Biasi, S., et al., (1999). Taylor's cortical dysplasia: a confocal and ultrastructural immunohistochemical study. Brain Patholology, Vol.9, No.3, (July), pp. 445-61, ISSN 1015-6305

Gyure, K.A., Sandberg, G.D., Prayson, R.A., Morrison, A.L., Armstrong, R.C., Wong, K., (2000). Dysembryoplastic neuroepithelial tumor: an immunohistochemical study with myelin oligodendrocyte glycoprotein. Archives of Pathology $\mathcal{E}$ Laboratory Medecine, Vol. 124. No.1, (January),pp. 123-6, ISSN 0003-9985

Henshall, D.C., Schindler, C.K., So, N.K., et al., (2004). Death-associated protein kinase expression in human temporal lobe epilepsy. Annals of Neurology, Vo.55, No.4, (April), pp. 485-94, ISSN 0364-5134

Herva, R., Tyynel, J., Hirvasniemi, A., Syrjkallio Ylitalo, M., Haltia, M., (2000). Northern epilepsy: a novel form of neuronal ceroid-lipofuscinosis. Brain Pathology, Vol.10, No.2, (April), pp. 215-22, ISSN 1015-6305

Hirose, T., Scheithauer, B.W., (1998). Mixed dysembryoplastic neuroepithelial tumor and ganglioglioma. Acta Neuropathologica (Berl), Vol. 95, No.6, (June), pp. 650-54, ISSN 0001-6322

Hisada K., Morioka, T., Nishio, S., Amano, T., Iwaki, T., Fukui, M., (1999). Temporal lobe epilepsy associated with old intracerebral hemorrhage due to capillary 
telangiectasis in the temporal lobe: case report. No To Shinkei, Vol.51, No.8, (August), pp. 729-35, ISSN 0006-8969

Jay, V., Becker, L.E., Otsubo, I.H., et al., (1995). Chronic encephalitis and epilepsy (Rasmussen's encephalitis): detection of cytomegalovirus and herpes simplex I by polymerase chain reaction and in-situ hybridization. Journal of Neurology, No.45, pp. 108, ISSN 0340-5354

Jay, V. \& Becker, L.E., (1994). Surgical pathology of epilepsy: a review. Pediatric Pathology $\mathcal{E}$ Molecular Medicine, Vol.14, No.4, (July), pp. 731-50, ISSN 1522-7952

Juhsz, C., Nagy, F., Muzik, O., Watson, C., Shah J., Chugani H.T., (1999). [11C]Flumazenil PET in patients with epilepsy with dual pathology. Epilepsia, Vol.40, No.5, (May), pp. 566-74, ISSN 0013-9580

Kuzniecky, R., Ho, S.S., Martin, R., et al., (1999). Temporal lobe developmental Malformations and hippocampal sclerosis: epilepsy surgical outcome. Neurology, Vol.52, No.3, (February), pp. 479-84, ISSN 0028-3878

Li, L.M., Cendes, F., Andermann F., et al., (1999). Surgical outcome in patients with epilepsy and dual pathology. Brain, No.122, (Pt 5), (May), pp. 799-805, ISSN 0006-8950

Louis, D.N., Ohgaki, H., Wiestler, O.D., Cavenee, W.K., (Eds.), (2007). WHO Classification of Tumors of the Central Nervous System, $4^{\text {th }}$ edition., IARC, ISBN 978-92-832-2430-2, Lyon, France

Marin-Padilla, M., (1999). Developmental neuropathology and impact of perinatal brain damage. III: gray matter lesions in the neocortex. Journal of Neuropathology and Exp Neurology, May, 58(5):407-29, ISSN 0022-3069

Mathern, G.W., Babb, T.L., Mischel, P.S., et al., (1996). Childhood generalized and mesial temporal epilepsies demonstrate different amounts and patterns of hippocampal neuron loss and mossy fiber synaptic reorganization. Brain, No.119, (Pt.3), (June), pp. 965-87, ISSN 0006-8950

Moreno, A., de Felipe, J., Garcia Sola, R., Navarro, A., Ramon, y., Cajal, S., (2001). Neuronal and mixed neuronal glial tumors associated to epilepsy. A heterogeneous and related group of tumours. Histology and Histopathology, Vol.16, No.2, (April), pp. 61322, ISSN 0213-3911

Niquet J., Wasterlain, C.G., (2004). Bim, Bad, and Bax: a deadly combination in epileptic seizures. The Journal of Clinical Investigation, Vol.113, No.7, (April), pp. 960-2, ISSN 0021-9738

15. Oda, M., Arai, N., Maehara, T., Shimizu, H., Kojima, H., Yagishita, A., (1998). Brain tumors in surgical neuropathology of intractable epilepsies, with special reference to cerebral dysplasias. Brain Tumor Pathology, Vol.15, No.1, pp. 41-51, ISSN 1433-7398

Palmini, A., Najm, I., Avanzini, G., et al., (2004). Terminology and classification of the cortical dysplasias. Neurology, No.62, pp. S2-S8, ISSN 0028-3878

Prayson, R.A., Estes, M.L., (1995). Cortical dysplasia: a histopathologic study of 52 cases of partial lobectomy in patients with epilepsy. Human Pathology, Vol.26, No.5, (May), pp. 503-500, ISSN 0046-8177

Prayson, R.A., Reith, J.D., Najm, I.M., (1996). Mesial temporal sclerosis. A clinicopathologic study of 27 patients, including 5 with coexistent cortical dysplasia. Archives of Pathology E Laboratory Medecine, Vol.120, No.6, (June), pp. 532-6, ISSN 0003-9985

Prayson, R.A., Bingaman, W., Frater, J.L., Wyllie, E., (1999). Histopathologic findings in 37 cases of functional hemispherectomy. Annals of Diagnostic Pathology, Vol.3, No.4, (August), pp. 205-12, ISSN 1092-9134

Prayson, R.A., (1999) Composite ganglioglioma and dysembryoplastic neuroepithelial tumor. Archives of Pathology E Laboratory Medicine, Vol.123, No.3, (March), pp. 24750, ISSN 0003-9985 
Prayson, R.A., Fong, J., Najm, I., (2010). Coexistent pathology in chronic epilepsy patients with neoplasms. Modern pathology, No.23, pp. 1097-1103, ISSN 0893-3952

Proper, E.A., Oestreicher, A.B., Jansen, G.H., et al., (2000). Immunohistochemical characterization of mossy fiber sprouting in the hippocampus of patients with pharmaco-resistant temporal lobe epilepsy. Brain, No.123, (Pt 1), (January), pp. 1930, ISSN 0006-8950

Rosemberg, S., \& Vieira, G.S., (1998). Dysembryoplastic neuroepithelial tumor. An epidemiological study from a single institution. Arqivos de Neuro-psiquiatria, Vol.56, No.2, (June), pp. 232-6, ISSN 0004-282X

Rushing, E.J., Barnard, J.J., Bigio, E.H., Eagan, K.P., \& White, C.L. 3 ${ }^{\text {rd }}$ (1997). Frequency of unilateral and bilateral mesial temporal sclerosis in primary and secondary epilepsy: a forensic autopsy study. The American Journal of Forensic Medicine and Pathology, Vol.18, No.4, (December), pp. 335-41, ISSN 0195-7910

Sisodiya, S.M., (2004). Malformations of cortical development: burdens and insights from important causes of human epilepsy. The Lancet Neurology, Vol.3, No.1, (January), pp. 29-38, ISSN 1474-4422

Spreafico R, Pasquier B, Minotti L, et al., (1998). Immunocytochemical investigation on dysplastic human tissue from epileptic patients. Epilepsy Research, Vol.32, No.1-2, (September), pp. 34-48, ISSN 0920-1211

Spanaki, M.V., Kopylev, L., Liow, K., DeCarli, C., et al., (2000). Relationship of seizure frequency to hippocampus volume and metabolism in temporal lobe epilepsy. Epilepsia, Vol.41, No.9, (September), pp. 1227-9, ISSN 0013-9580

Uysal H, Cevik IU, Soylemezoglu F, et al., (2003) Is the cell death in mesial temporal sclerosis apoptotic? Epilepsia, Vol.44, No.6, (June), pp. 778-84, ISSN 0013-9580

Volk, E.E, Prayson, R.A. (1997). Hamartomas in the setting of chronic epilepsy: a clinicopathologic study of 13 cases. Human Pathology, Vol.28, No.2, (February), pp. 227-32, ISSN 0046-8177

Wang, V.Y., Chang, E.F., Barbaro, \& N.M., (2006). Focal cortical dysplasia: A review of pathological features, Genetics, and surgical outcome. Neurosurgery Focus, Vol.20, No.1, ISSN 1092-0684. Accessed on 21 Mar 2011. Available from: www.medscape.com/viewarticle/522325.

Whittle, I.R, Dow, G.R., Lammie, G.A., \& Wardlaw J., (1999). Dsyembryoplastic neuroepithelial tumour with discrete bilateral multifocality: further evidence for a germinal origin. British Journal of Neurosurgery, Vol.13, No.5, (October), pp. 508-11, ISSN 0268-8697

Wolf HK., Wellmer J., Muller M.B., Wiestler O.D., Hufnagel A., \& Pietsch, T., (1995). Glioneuronal malformative lesions and dysembryoplastic neuroepithelial tumors in patients with chronic pharmacoresistant epilepsies. Journal of Neuropathology and Experimental Neurology, Vol.54, No.2, (March), pp. 245-54, ISSN 0022-3069

Wolf, H.K.\& Wiestler, O.D., (1993) Surgical pathology of chronic epileptic seizure disorders. Brain Pathology, No.4, (October 3), pp. 371-80, ISSN 1015-6305

Wolf, H.K., Birkholz, T., Wellmer, J., Blumcke, I., Pietsch, T., Wiestler, O.D., (1995) Neurochemical profile of glioneuronal lesions from patients with pharmacoresistant focal epilepsies. Journal of Neuropathology and Experimental Neurology, Vol.54, No.5, (September), pp. 689-97, ISSN 0022-3069

Zix, C., Billard, C., Motte, J., (1999) Epilepsy due to mesiotemporal sclerosis in children: 10 cases. Archives de Pediatrie, Vol.6, No.4, (April), pp. 398-405, ISSN 0929-693X 


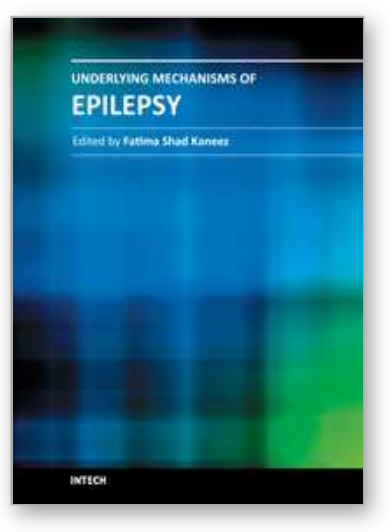

\author{
Underlying Mechanisms of Epilepsy \\ Edited by Prof. Fatima Shad Kaneez
}

ISBN 978-953-307-765-9

Hard cover, 354 pages

Publisher InTech

Published online 26, September, 2011

Published in print edition September, 2011

This book is a very provocative and interesting addition to the literature on Epilepsy. It offers a lot of appealing and stimulating work to offer food of thought to the readers from different disciplines. Around $5 \%$ of the total world population have seizures but only $0.9 \%$ is diagnosed with epilepsy, so it is very important to understand the differences between seizures and epilepsy, and also to identify the factors responsible for its etiology so as to have more effective therapeutic regime. In this book we have twenty chapters ranging from causes and underlying mechanisms to the treatment and side effects of epilepsy. This book contains a variety of chapters which will stimulate the readers to think about the complex interplay of epigenetics and epilepsy.

\title{
How to reference
}

In order to correctly reference this scholarly work, feel free to copy and paste the following:

Assaad Fawaz and Al Khani Raydeh (2011). Histopathological Changes in Temporal Epilepsy, Underlying Mechanisms of Epilepsy, Prof. Fatima Shad Kaneez (Ed.), ISBN: 978-953-307-765-9, InTech, Available from: http://www.intechopen.com/books/underlying-mechanisms-of-epilepsy/histopathological-changes-in-temporalepilepsy

\section{INTECH}

open science | open minds

\section{InTech Europe}

University Campus STeP Ri Slavka Krautzeka 83/A 51000 Rijeka, Croatia

Phone: +385 (51) 770447

Fax: +385 (51) 686166 www.intechopen.com

\section{InTech China}

Unit 405, Office Block, Hotel Equatorial Shanghai No.65, Yan An Road (West), Shanghai, 200040, China 中国上海市延安西路65号上海国际贵都大饭店办公楼405单元 Phone: +86-21-62489820

Fax: +86-21-62489821 
(C) 2011 The Author(s). Licensee IntechOpen. This chapter is distributed under the terms of the Creative Commons Attribution-NonCommercialShareAlike-3.0 License, which permits use, distribution and reproduction for non-commercial purposes, provided the original is properly cited and derivative works building on this content are distributed under the same license. 